\title{
Rimbert's Vita Anskarii and Scandinavian Mission in the Ninth Century
}

\author{
by JAMES T. PALMER
}

The idea of converting Scandinavia to Christianity had been enthusiastically pursued by the Emperor Louis the Pious and Archbishop Ebbo of Rheims in the 82os. Optimism such as theirs was, however, not to last, and little progress was made between the death of Archbishop Rimbert of Hamburg-Bremen in 888 and the conversion of Harald Bluetooth a century later. This article examines how Rimbert wrote a saint's Life about Anskar, his predecessor and 'apostle of the north', in an attempt to arrest the waning support for the mission. It considers how this was achieved by placing the text in the context of the clashes between Ebbo and his successor, Hincmar, the predestination debate and the idea that mission was fulfilling apocalyptic prophecies.

'In the time of Lord Louis [the Pious, d. 840] the emperor, [Archbishop Ebbo of Rheims] travelled to Rome with [Louis's] consent and by the power of all the congregation of his kingdom's synod; and there [Ebbo] was given licence to publicly evangelise the northern regions by the venerable pope, Paschal [in 82I]. And how much afterwards did the emperor, Louis, encourage this work; and he offered plenty in everything and kindness et caetera ... [and now] the church of Christ has been founded amongst the Danes and amongst the Swedes and priests perform their proper office without prohibition'. 1 Hamburg-Bremen, writing in 864, summarised the achievements of the first organised missions to Scandinavia. His purpose in writing was to encourage King Louis the German (d. 876) and all the bishops of the

MGH Epp. $=$ MGH Epistolae; MGH SS $=$ MGH Scriptores; MGH SS rer. Germ. $=$ MGH Scriptores rerum Germanicarum in usum scholarum; MGH SS rer. Mer. = MGH Scriptores rerum Merovingicarum in usum scholarum

My thanks to Sarah Foot and the anonymous readers for this Journal for the helpful advice and suggestions offered about this article. I would also like to thank Rosamond McKitterick for her invaluable help with the Cambridge MPhil. thesis from which this work developed.

1 Epistolae variorum, no. I6, ed. E. Perels, MGH Epp., vi. I63. 
East Franks to offer sufficient support to bring the missions to fruition. ${ }^{2}$ Anskar had that year been bolstered by news that the controversial unification of his diocese of Hamburg with Bremen had, after fourteen years, been approved by a pope, Nicholas I, enthusiastic for mission. However, the archbishop was nearing death and feared that after he had gone the missions would be forgotten; thus he urged the bishops to 'store this letter away readily in your library for perpetual memory where it can be examined easily and be known to all' ${ }^{3}$ The letter therefore leads us to ask what had happened to the missions and support for them since the days of Louis and Ebbo that forced Anskar to publicise them in this manner?

There remains little information on the missions of Ebbo and Anskar aside from Anskar's letter. Our primary source is the Vita Anskarii, a saint's Life written about the missions by Anskar's successor, Rimbert, sometime between 869 and 876, and addressed to the monastery of Corbie in Flanders. The work is almost unparalleled in the ninth century in its style, complexity and for the information it provides about the north. Apart from the Vita Anskarii, there are two perfunctory references to Ebbo's first mission to Denmark in 823 in contemporary annals, ${ }^{4}$ four accounts of the subsequent baptism of a Danish king, Harald Klak, at Louis the Pious's court in $826^{5}$ and three further references in annals to the death of Anskar in $865 .{ }^{6}$ A vast array of archaeological evidence has also been unearthed from Anskar's mission fields of Hedeby and Ribe in Denmark, and Birka in Sweden, that helps enrich our understanding of the world described by Rimbert, although it does little to answer the questions raised here. ${ }^{7}$ It is difficult to gauge precisely how the missions were viewed by potential patrons amongst the Franks with this paucity of evidence. There are a number of questions that can usefully be asked of our sources: Why is the evidence so sparse? Why did Rimbert use the genre of hagiography to record the missions rather than history or letters? Why did he choose a West Frankish audience rather than write to the East Franks to whom Anskar had written? What factors made Corbie in particular a target for Rimbert's work? I will proceed by considering Rimbert's

${ }^{2}$ Rimbert, Vita Anskarii 4I, ed. G. Waitz, SS rer. Germ., lv. 75.

3 Epistolae variorum, no. I6, I63.

4 Annales regni francorum s.a. 823, ed. F. Kurze, MGH SS rer. Germ., vi. ı63; Annales xantenses et Annales vedastini s.a. 823, ed. B. v. Simson, MGH SS rer. Germ., xii. 6.

${ }^{5}$ Ermoldus Nigellus, In honorem Hludowici, bk iv, lines $148-456$, ed. E. Dümmler, MGH Poetae, ii. 62-70; Thegan, Gesta Hludowici imperatoris 33, ed. E. Tremp, MGH SS rer. Germ., lxi. 220; Astronomer, Vita Hludowici imperatoris 4o, ed. E. Tremp, MGH SS rer. Germ., lxi. 43I; Annales regni francorum s.a. 826, I69-70.

6 Annales xantenses s.a. 866 (recte 865), 22; Annales corbeienses s.a. 865, ed. G. H. Pertz, MGH SS iii. 3 ; Annales quedlinburgenses s.a. 865 , ed. G. H. Pertz, MGH SS iii. 48 .

7 For Hedeby see Herbert Jankuhn, Haithabu, Neumünster i986; on Ribe see Stig Jensen, The Vikings of Ribe, trans. Geoffrey Bibby, Ribe ı99ı ; on Birka see Björn Ambrosiani and Helen Clarke (eds), Early investigations and future plans, Stockholm 1992. 
personal interests, the East Frankish context in which he was writing, how the Vita Anskarii related to Corbie in the 87os and, finally, the importance of the see of Rheims to the missions in the ninth century.

\section{Rimbert and the East Frankish context of the missions}

Rimbert remains a shadowy figure in the history of the ninth century. ${ }^{8}$ Most of the direct information about him comes from the somewhat unsatisfactory Vita Rimberti, written sometime between his death in 865 and 909. ${ }^{9}$ This is a problematic text because the author, whoever he or she may be ${ }^{10}$ was at pains to bind the memory of Rimbert as closely to Anskar as possible. Rimbert had been considered rather young to assume the role of archbishop in 888, so the Vita Rimberti was careful to stress that, having never left his teacher's side, he was Anskar's rightful successor. This appeared to be confirmed in the text when no one opposed his appointment in $865 .{ }^{11}$ What facts might have been sacrificed or altered to achieve this effect, we can but guess. The Vita Rimberti also portrays Rimbert as a leading bishop at the court of Louis the German, but there is reason to be suspicious about this too. ${ }^{12}$ On the other hand there is no reason not to believe the Vita Rimberti when it says that Rimbert was brought up in the monastery of Turnhout in Flanders. ${ }^{13}$ This is significant, because Rimbert himself reported that this monastery had been given to Anskar to provide material support for the mission and to train Danish boys for preaching in their native land ${ }^{14}$ Rimbert was, therefore, likely to have been trained for involvement in Ebbo and Anskar's missions. If the Vita Rimberti

8 The one scholarly work to focus on the life of Rimbert rather than his Vita Anskarii is Andreas Röpke, 'Pro memoria Remberti', in Rimbert der Nachfolger Ansgars, Hamburg 2000, 30-56. Röpke laments that Rimbert's memory is always over-shadowed by Anskar, even in Hamburg today, despite the achievement of the Vita Anskarii.

9 Vita Rimberti, ed. G. Waitz, MGH SS rer. Germ., lv.

10 Until recently, there had been little progress from G. Pertz's assertion in MGH SS ii. 764 that it was probably written somewhere under, but not by, Rimbert's successor Adalgar. Röpke described it as having 'the art and listless production of a requested work' ('Pro memoria Remberti', 48-9), but refused to be drawn further. Since then Theodor Klüppel, 'Die Gerania (750-950)', in G. Philippart (ed.), Hagiographies, ii, Turnhout I996, I6I-209 at p. 20I, has suggested that it was written in Corvey on the basis of segments about the monastery, but Ian N. Wood, The missionary life: saints and the evangelisation of Europe, 400-I050, Harlow 200I, I35, has suggested rather that the author came from the nunnery of Nienheerse on the basis of the text's inclusion of a letter about virginity that Rimbert wrote to a nun there. The broad consensus seems to remain that it was written for Adalgar, since both Corvey and Nienheerse were under his jurisdiction.

11 Vita Rimberti 6, Io, pp. 84-5, 88-9.

12 Compare ibid. 20, pp. 96-7, which appears to refer to an incident involving Charles the Fat in 873 , with Annales bertiniani s.a. 873, ed. G. Waitz, MGH SS rer. Germ., v. I22-3; Annales fuldenses s.a. 873, ed. F. Kurze, MGH SS rer. Germ., vii. 77-8; Annales xantenses s.a. 873, 31-2. None of these other sources mention Rimbert at all.
13 Vita Rimberti 3, p. 83 .
${ }^{14}$ Rimbert, Vita Anskarii I5, pp. 36-7. 
is to be believed, Rimbert left the monastery while still young to accompany Anskar on his journeys, giving him first-hand experience of the mission field. He may also have been sent as a priest to Birka in Sweden early in the 86os as the Vita Anskarii records a Danish priest called Rimbert making the journey. ${ }^{15}$ Scholarly consensus has been to deny that the two Rimberts were identical because of the silence of the Vita Rimberti on the matter, ${ }^{16}$ but it is not a reliable witness given that the work refused to separate Anskar and Rimbert before Anskar's death. Furthermore, it might be plausible that Rimbert was Danish, since he came from Turnhout. If Rimbert was Danish then the desire to save his own people might have motivated a desire to encourage the missions, just as it had for Boniface in Saxony over a century earlier. ${ }^{17}$

Rimbert's interest in missionary work does not appear to have diminished after Anskar's death. The Vita Rimberti reports that he continued to spend time preaching to the Danes in Hedeby. He also wrote a letter to Ratramnus of Corbie, asking whether cynocephali (dog-headed men) were monsters, or men in need of mission. ${ }^{18}$ The letter should be seen in the context of references to the end of the world and the ends of the earth in Isaiah xlix. $5^{-7}$ and Matthew xxiv. I4 in the Vita Anskarii. ${ }^{19}$ For Rimbert, Scandinavia was the end of the known world geographically, making it difficult for him not to see the missions as a fulfilment of prophecy. ${ }^{20}$ It would also have been difficult for Rimbert to abandon the work. It may therefore be significant that he started to write the Vita Anskarii at a time when problems with his feet meant that he could no longer play the role of an active pastor and preacher ${ }^{21}$ In the introduction to the Vita Anskarii, Rimbert says that he wrote 'to make known how [Anskar] lived amongst us, and record what we know of him, in order that ... his most sacred devotion may make an example of salvation for those wishing to imitate him' (my italics). ${ }^{22}$ In a sense, the significance of Christian history in general lies in its message of salvation. ${ }^{23}$ Statements such as Rimbert's should therefore not be written off as mere topoi. Hagiographers would take care in sculpting an image of sanctity for their readers to emulate, although in turn

15 Ibid. 33, p. 64 .

16 Scepticism was noted by Waitz and has recently been reiterated by Hilde Rieper in the latest German edition of the two saints' Lives, Ansgar und Rimbert: die beiden ersten Erzbischöfe von Hamburg-Bremen und Nordalbingen, Hamburg 2000, 77 n. 4.

17 Die Briefe des Heiligen Bonifatius und Lullus, no. 46, ed. M. Tangl, MGH Epp. Selectae, i. $74-5$.

18 The initial letter has not survived, but see Ratramnus' reply in Epistolae variorum, no. I2, MGH Epp., vi. I55-7. On the letter see Röpke, 'Pro memoria Remberti', 34-6.

19 Rimbert, Vita Anskarii 25, 34, 38, pp. 55, 65, 73; Ian N. Wood, 'Christians and pagans in ninth-century Scandinavia', in P. H. Sawyer, B. Sawyer and I. N. Wood (eds), The Christianization of Scandinavia, Alingäs I987, 36-67 at pp. 63-5.

20 Wood, 'Christians and pagans', 63. $\quad 21$ Vita Rimberti 21, p. 97.

22 Rimbert, Vita Anskarii I, p. 20.

${ }^{23}$ Karl Löwith, Meaning in history, Chicago-London I949, esp. p. I85. 
this would be designed with the audience's interests in mind. To understand Rimbert's overall purpose, it is necessary to understand what examples he thought should be imitated and how these related to his concerns with mission, prophecy and salvation; we must also understand the Corbie monks' attitudes to the same issues in order to explain why they might have been potential patrons.

The Vita Anskarii is a highly complex work and there are a number of different themes interwoven into the text. Hagiographies had developed from the genre of classical biography, which was written to illustrate particular ideas rather than history. ${ }^{24}$ Authors could also twist the truth, if not lie outright, if it contributed to a greater purpose. ${ }^{25}$ Furthermore, as Ian Wood has shown recently, as hagiography developed it became not a single genre but adopted a multiplicity of interlocking forms, being written for a number of spiritual and political ends. ${ }^{26}$ In the Vita Anskarii, distinct theological, personal and political concerns have been recognised. The theological aspect was revealed in Rimbert's concern to use visions and miracles to illustrate ideas of predestination, divine retribution and the rewards of constancy of faith. ${ }^{27}$ These ideas could be connected to the idea of mission because they would serve to strengthen the resolve of potential missionaries, hesitating to enter the unknown north. At the same time, Ian Wood has suggested that the text amounts to a personal meditation about the problems of mission, albeit a meditation intended equally for public circulation. ${ }^{28}$ Several commentators have also explored the political functions the Vita Anskarii served in defending the unification of Hamburg and Bremen. ${ }^{29}$ According to this reading, Rimbert structured the text so that the unification of Hamburg and Bremen

${ }^{24}$ Clare Stancliffe, Saint Martin and his hagiographer: history and miracle in Sulpicius Severus, Oxford 1983,88, I87. 25 Ibid. $185^{-6 .}$

${ }^{26}$ Ian N. Wood, 'The use and abuse of Latin hagiography in the early medieval west', in E. Chrysos and I. N. Wood (eds), East and west: modes of communication, Leiden I999, 93-109 at p. 93 .

${ }_{27}$ Wolfdieter Haas, 'Foris apostolus - intus monachus: Ansgar als Mönch und "Apostel des Nordens", , Fournal of Medieval History xi (1985), I-30; Wood, 'Christians and pagans', 39-40, and The missionary life, $127-35$.

28 Wood, The missionary life, I34. The difference between public and private works in general has been expounded clearly in Janet L. Nelson, 'Public histories and private history in the work of Nithard', Speculum lx (I985), 25 ${ }^{\mathrm{I}-93}$.

${ }^{29}$ See Richard Drögereit, 'Hamburg-Bremen, Bardowick-Verden Frühgeschichte und Wendenmission', Jahrbuch des Vereins für westfälische Kirchengeschichte li (I969), I93-201 ; Richard Drögereit, 'Erzbistum Hamburg, Hamburg-Bremen oder Erzbistum Bremen?', Archiv für Diplomatik xxi (1975), I36-230; Wolfgang Seegrün, Das Erzbistum Hamburg in seinen älteren Papsturkunden, Cologne-Vienna i976; Gerhard Theuerkauf, 'Urkundenfälschungen des Erzbistums Hamburg-Bremen vom 9. bis 12. Jahrhundert', Niedersächsisches Fahrbuch für Landesgeschichte $\mathrm{lx}$ (1988), 7I-I40; Brigit Wavra, Salzburg und Hamburg: Erzbistumgründung und Missionspolitik in Karolingischer Zeit, Berlin I99I; Wolfgang Seegrün, 'Erzbischof Rimbert von Hamburg-Bremen im Erbe des päpstlichen Missionsauftrages', in Rimbert der Nachfolger Ansgars, 57-72; Wood, The missionary life, I26-7. 
was described roughly half-way through, giving it pride of place and creating the illusion of a longer and more successful tradition for the new diocese. ${ }^{30}$ The description was given authority by the inclusion of the text of Nicholas I's letter of 864 confirming the unification. ${ }^{31}$ The letter discusses the basis of the missions, and has thus been taken to show how Rimbert used the missions to justify the unification. ${ }^{32}$ However, we might wonder, given that the Vita Anskarii was for a monastic rather than political audience, and that saints' Lives written for such audiences usually had liturgical functions, ${ }^{33}$ why Rimbert should have written to West Frankish monks at Corbie about an East Frankish political situation in which they were unlikely to be able to help. Perhaps more likely is that the situation in the Vita Anskarii was the other way around: rather than the mission justifying the unification, the unification justified the mission. As we shall see below, the mission might well have been something Rimbert hoped the monks might be involved with. The different functions of the Vita Anskarii are therefore unified by a single, overriding concern: the continuation of mission in the north.

If it can be argued that one of Rimbert's purposes in writing was to establish the missionary credentials of Hamburg-Bremen, it is surprising to note that Rimbert omitted to mention Bremen's founding father, Willehad. He had been a Northumbrian missionary who worked in Saxony and Frisia in the 780 s at a time when Charlemagne was asserting his authority in those same regions. An anonymous vita was written about his life sometime before the $830 s,{ }^{34}$ and Anskar wrote a Miracula Willehadi about an outbreak of miracles at the saint's tomb in $860 .{ }^{35}$ It has been argued that Anskar did not know the Vita Willehadi because he did not use it in the Miracula. ${ }^{\mathbf{3 6}}$ However, the Miracula should be seen as being written to complement the Vita: they both start with theological justifications for worshipping saints and, since the Miracula simply extends the story of the Vita, there is no logical reason why Anskar had to borrow from the earlier work. Perhaps tellingly, the Miracula always follows the Vita in surviving manuscripts, ${ }^{37}$ and Adam of Bremen

\footnotetext{
${ }^{30}$ Rimbert, Vita Anskarii 22-33, pp. 47-51; Wood, 'Christians and pagans', 38, and The missionary life, $126-7$.

${ }^{32}$ Seegrün, 'Erzbischof Rimbert', 60.

${ }^{33}$ Rosamond McKitterick, The Carolingians and the written word, Cambridge I989, 24I-3; Katrien Heene, 'Merovingian and Carolingian hagiography: continuity or change in public and aims?', Analecta Bollandiana cvii (1989), 4155-28.

34 Vita Willehadi, ed. A. Poncelet, Acta sanctorum, Nov. iii. 8th, $847^{-5}$ I. The genesis of the work is somewhat unclear. The original view of Poncelet, recently reasserted by Klüppel in 'Die Germania', I98, was that it was written by a Bremen cleric. Gerlinde Niemeyer, 'Die Herkunft der Vita Willehadi', Deutsches Archiv xii (1956), I7-35- an article which needs closer consideration - has suggested that it was written at Echternach, near Trier, and her views have recently found support in Wood, The missionary life, 90-I.

${ }^{35}$ Miracula Willehadi, ed. A. Poncelet, Acta sanctorum, Nov. iii. 8th, 847-51. See Wood, missionary life, 132 , for the latest view on the text. ${ }^{36}$ See Niemeyer, 'Die Herkunft', I8.

37 Poncelet, Acta sanctorum, Nov. iii. 840.
} 
thought from Anskar's preface to the Miracula that he had written the Vita as well. ${ }^{38}$ Nicholas I's confirmation of the unification of Hamburg-Bremen in 864 changed everything. Willehad had been closely associated with Bremen alone but now, since Bremen no longer existed as a unitary see, the cult of Willehad counted against the unification with Hamburg. Rimbert's suppression of Willehad therefore had the effect of recasting Bremen as part of the same diocese as Hamburg, uniting them under a common 'saint' in Anskar. The binding of saints' cults to particular places was clearly a sensitive issue for Rimbert.

The unification of Hamburg and Bremen had put Rimbert in a difficult position for obtaining support from the East Franks. The Annales xantenses and Annales fuldenses - written at Cologne and Mainz respectively - do not even mention the unification. This is surprising, because both sees lost land as a consequence of the merger, and Rimbert reports that the archbishop of Cologne and the bishop of Verden opposed the move at meetings in Mainz. It seems that Hamburg-Bremen came to be perceived as a second-rate archbishopric, marginalised by its lack of suffragan bishops, and on an uncertain footing at East Frankish synods. ${ }^{39}$ When the Annales fuldenses actually mentioned Rimbert, they called him bishop of Norden in Frisia by mistake - hardly what we expect about one of Louis's supposed leading bishops. ${ }^{40}$ It might be important that Saxony in the ninth century was only imperfectly Christian, poor and dangerous - conditions that are confirmed by Rimbert. ${ }^{41}$ This meant that churches there found it very difficult to attract benefactors and, consequently, material support for activities beyond pastoral duties. The region suffered a lack of strategic importance following the Frankish civil war of $840^{-}-3$, as is illustrated by the fact that King Louis the German visited the region only three times in the thirty years after the Treaty of Verdun. ${ }^{42}$ This attitude probably arose because Saxony had become a relatively stable frontier, largely ignored by the viking raiders and warbands of the period and predominantly receptive to the Franks - at least after Louis the German had quelled the Stellinga uprising in $842 .{ }^{43}$ In the meantime, the court of Louis the German had become far more concerned with the actions of the Slavs to the east than happenings in the north. With no rich sponsors

38 Adam of Bremen, Gesta hammaburgensis ecclesiae pontificum i. I3 (I4), ed. B. Schmeidler, MGH SS rer. Germ., ii. I7.

39 Seegrün, 'Erzbischof Rimbert', 63.

40 Annales fuldenses s.a. 884, Iог.

${ }^{41}$ Christopher Carroll, 'The bishoprics of Saxony in the first century after Christianisation', Early Medieval Europe viii (1999), 219-45; Seegrün, 'Erzbischof Rimbert', 59; Rimbert, Vita Anskarii 38, pp. 72-4. The position of Saxony by 876 does not, of course, reflect its strong position by the beginning of the tenth century: Matthias Becher, Rex, dux und gens: Untersuchungen zur Entstehung des sächsichen Herzogtums im 9. und Io. Jahrhundert, Husum I996.

${ }^{42}$ Johannes Fried, 'The Frankish kingdoms, 817-911: the east and middle kingdoms', in R. McKitterick (ed.), The new Cambridge medieval history, II: c. 70o-c. Iooo, Cambridge I995, I $42^{-6}-68$ at pp. I $44^{-5}, \mathrm{I} 48$.

43 Annales fuldenses s.a. 842,33 . 
and working from a poor and isolated position, any mission would break down without renewed material support. ${ }^{44}$ This would explain why Rimbert was forced to promote the missions to the West Frankish kingdom.

\section{A missionary model for Corbie}

The monastery of Corbie was a natural place for Rimbert to turn for support. Some of its monks were already familiar with Anskar, who had been a monk there himself. A connection between Hamburg-Bremen and Corbie might also have been maintained because both had close links with the monastery of Corvey. Yet it is factors specifically pertaining to Corbie in the 86os and 870 that made the monastery a natural recipient of the Vita Anskarii. Some monks from Corbie, in particular Ebbo's friend Gottschalk and Rimbert's friend Ratramnus, stood in opposition to Hincmar over the issue of double predestination. The debate was one of the most heated of the day. For Rimbert, it may also have opened up a route to the West Frankish king, Charles the Bald.

Corbie had had close ties with the Carolingian family; the abbots Adalhard (d. 826) and Wala (d. 836) were, for example, both cousins of Charlemagne. Charles the Bald had maintained a positive relationship with Corbie, and had sponsored Nicholas I's grant of privileges to the monastery in 863 and again in $875 .{ }^{45} \mathrm{He}$ also had a history of building relations with the Danes in his kingdom, most notably when Weland and his family converted at the king's court in 862 and when he negotiated with Roric and Rodulf in $872{ }^{46}$ But he had not followed the example of his father, Louis the Pious, and used the resources in West Frankia to support Anskar; on the contrary, when the empire of the deceased Louis was divided between his three sons in 843 , Charles had received Rimbert's former monastery of Turnhout, but had severed its connections to Anskar by giving it to one Raginar. ${ }^{47}$ This, Rimbert reveals, nearly brought an end to missions because of the strain it put on Hamburg's material resources. By the time Rimbert came to write the Vita Anskarii, Charles might have been more responsive to supporting missions from East Frankia: the death of Lothar II in 869 had led to the West Franks expanding eastwards to Aachen and growing tensions with the East Franks which Rimbert might have wanted to exploit. ${ }^{48}$ Charles also had, through

44 This is the main thrust of Jane Stevenson's argument in her, 'Christianising the northern barbarians', in J. F. Krøger and H.-R. Naley (eds), Nordsjøen: Handel, religion og politikk, Stavanger 1996, I62-84 at p. I79. Her argument could, however, have been given more force by a closer consideration of the more immediate context of Hamburg-Bremen and its potential patrons in the ninth century.

45 Recuil des actes de Charles II le Chauve ii. 423, ed. M. G. Tessier, Paris 1952, 444-6.

46 Annales bertiniani s.a. 862, 872, 58, I2 I. ${ }^{47}$ Rimbert, Vita Anskarii 2 I, pp. 46-7.

48 Annales bertiniani s.a. 870 , 108. 
Corbie, a relationship with Nicholas I who, lest we forget, had been a keen supporter of mission and mentioned Turnhout in his letter confirming the unification of Hamburg-Bremen. ${ }^{49}$ Rimbert may have felt that conditions had changed sufficiently for Charles to be open to returning Turnhout to Hamburg-Bremen; the chapter mentions previous negotiations between Corbie monks and Charles over the matter but, since it is made clear how much better off the mission was with the monastery, the indication is perhaps that the time was right to ask again. ${ }^{\mathbf{5 0}}$

A significant factor in this change of circumstances was likely to have been the predestination debate. ${ }^{\mathbf{5 1}}$ This had originated in the writings of a Saxon monk called Gottschalk, who had stayed at Fulda and Corbie. Gottschalk's questions seem to have arisen in the context of the uncertainties of creating a new Christian society in the recently-converted Saxony. ${ }^{\mathbf{5}}$ The debate also belongs in the context of the Carolingian preoccupation with sin that dominated much of ninth-century theology as clerics tried to rationalise why the pagan northmen were having so much success raiding against Christians. ${ }^{53}$ Worries about the nature of salvation might also have spread into the Scandinavian mission field as Gislemar, a Corbie monk who was sent by Abbot Wala to tend to the Christians at Harald Klak's court, ${ }^{\mathbf{5 4}}$ was one of the recipients of Gottschalk's writings. ${ }^{\mathbf{5 5}}$ Rimbert was notably sympathetic to Gottschalk's ideas and there is a strong predestination theme in the Vita Anskarii. ${ }^{\mathbf{5 6}}$ With his concern to illustrate mission in relation to prophecy and salvation, especially in the context of creating a new Christian society in the north, it was natural for Rimbert to include such themes in the Vita. It also neatly illustrates the reflexive relationship between the author of a saint's Life and his audience, where the author uses his knowledge of his audience's expectations and interests to guide his writings and manipulate their responses to it. ${ }^{\mathbf{5 7}}$ Charles the Bald is an interesting figure in this context because he had turned to Ratramnus to offer a riposte to the theories of his own advisor, Archbishop Hincmar of Rheims, suggesting that he was closer to Corbie's position than that of Hincmar. ${ }^{58}$ It is also worth noting that Pope Nicholas, who was linked to Charles and Corbie through the charter of 863 mentioned above, also allegedly agreed with double predestination. ${ }^{\mathbf{5 9}}$

49 Rimbert, Vita Anskarii 23, p. 5 o.

50 Ibid. 2I, pp. 46-7.

${ }^{51}$ On the predestination dispute see David Ganz, 'The debate on predestination', in M. T.

Gibson and J. L. Nelson (eds), Charles the Bald: court and kingdom, London I990, 283-302.

${ }^{52}$ David Ganz, Corbie in the Carolingian Renaissance, Sigmaringen i99o, 88.

53 Simon Coupland, 'The rod of God's wrath or the people of God's wrath? The Carolingian theology of the Viking invasions', this Journal xlii (I99i), 535-54 at p. 539.

${ }_{54}$ Rimbert, Vita Anskarii Io, p. 3 I.

${ }^{55}$ Ganz, Corbie, 87.

56 Wood, 'Christians and pagans', 39.

57 See Hippolyte Delehaye, Legends of the saints, trans. R. Attwater, Dublin r998, esp. pp. $5 \mathrm{O}^{-}-2$.

58 Ganz, Corbie, 33.

${ }^{59} \mathrm{~J}$. L. Nelson, The Annals of St Bertin, Manchester i99I, IO-II. 
Rimbert was thus locating the missions in the intellectual world of a group of powerful figures - Charles, Nicholas and Ratramnus - that he would have hoped could offer him support.

The Vita Anskarii, apart from displaying sympathies for predestination theory, also had close intellectual links with the works of Paschasias Radbertus, an abbot of Corbie in the 84os. The musings that accompany the descriptions of visions seem to invite comparisons with Radbertus' own theological speculations, although there are differences. ${ }^{60}$ Rimbert also appears to have used Radbertus' discussion of grief in chapters iii-vi of the Vita sancti Adalhard in formulating his own grief over the loss of his teacher ${ }^{61}$ as well as parts of the Epitaphium Arsenii on comparisons between Job and Wala ${ }^{62}$ These uses of Job are highly unusual in vitae of the period and can only be found in the works of three writers: Radbertus, Rimbert and Hincmar. ${ }^{63}$ Ian Wood has drawn our attention to the significance of such clusters of texts and how they can relate to the intellectual and power struggles within which they are produced ${ }^{64}$ Hincmar himself was not without his connections to Corbie, as Radbertus had 'resigned' and been replaced by Hincmar's protégé Odo - who was later involved in Nicholas's grant to Corbie as bishop of Beauvais - sometime in the 85os. Odo had subsequently been a mediator of sorts between Hincmar and Ratramnus on theological issues. ${ }^{65}$ Thus the worlds of Hincmar and Rimbert had overlapped at Corbie. But most significantly, Radbertus saw the building of churches in Scandinavia, alongside Carolingian civil war and viking raids, as an indication that apocalyptic Scripture was being fulfilled. ${ }^{66}$ The theological position also helped to reinforce the divisions created by the predestination debate: figures like Hincmar and Hrabanus Maurus of Mainz who opposed double predestination are also notable for their more sober, historical evaluation of the northmen. ${ }^{67}$ None the less, Radbertus clearly influenced Rimbert's conception of what was occurring in the north. Since it was from a former abbot of Corbie that Rimbert had derived the ideas of prophecy and salvation he applied to promoting the mission, Corbie was therefore also a natural place to send the Vita Anskarii in the hope of receiving a positive response.

The conception of the missions as the fulfilment of Scripture had an important bearing on the Corbie monks' licence to help the missions. As a monastic house of the Carolingian empire, Corbie adhered to the Rule of

60 Haas, 'Foris apostolus', I4.

61 Wilhelm Levison, 'Zur Würdigung von Rimberts vita Anskarii', in his Aus Rheinischer und Frankischer Frühzeit, Dusseldorf I948, 610-30 at p. 6rig.

${ }^{62}$ Wood, 'Christians and pagans', 63. 63 Ibid.

${ }^{64}$ Idem, 'Missionary hagiography in the eighth and ninth centuries', in K. Brunner and B. Merta (eds), Ethnogenese und Überlieferung: Angewandte Methoden der Frühmittelalterforschung, Vienna 1994, I89-9, expanded upon in Wood, The missionary life.

${ }^{65}$ Ganz, Corbie, 34 .

${ }_{66}$ Paschasius Radbertus, Expositio in Matthaeum xi.24, xxiv.6-7, I4, in $P L$ cxx. $306 \mathrm{~B}-7 \mathrm{~A}$, 80 B- $\mathrm{C}, 805 \mathrm{C}-\mathrm{D}$.

67 Coupland, 'The rod of God's wrath', 538 . 
Benedict. Provisions in the rule condemned extensive wanderings and instructed that monks should live in stabilitas. ${ }^{68}$ Pope Gregory the Great had, in sending monks as missionaries to England, indicated that monks could go into the mission field. ${ }^{69} \mathrm{He}$ had also stipulated that where monks were needed as priests for a prolonged time, they were to be ordained and should sever their ties with monasteries; the principle that Benedictine monks should not be involved in the world outside the monastery was generally accepted at this time. ${ }^{70}$ Monks could be sent outside the cloister on short, important business by their abbot. Indeed, we find that Rimbert tells us that it was Wala, Anskar's abbot, who recommended the young monk to Louis the Pious as a man well-suited to teaching pagans because of the aptitude he had shown in teaching Saxon boys at Corvey. ${ }^{71}$ The decision to preach in the north was therefore made by an emperor and an abbot, not by a wilful young monk. It was, however, not until Anskar returned from Sweden in 83I that he was ordained as a bishop, so Rimbert had to explain why the mission was so important that monks could ignore vows of stabilitas for years at a time; this, for whatever reason, he left until Anskar had nearly finished his active missionary life. For effect, Rimbert attributed to Anskar a vision of Adalhard, Wala's older brother and another abbot of Corbie and founder of Corvey, shortly before the missionary returned to Birka in $c .852 .{ }^{72}$ Significantly, Adalhard is presented quoting prophecies from Isaiah, including xlix.5-7 on converting the Gentiles and taking Christianity 'unto the end of the Earth'. There then follows a discussion on how Isaiah's prophecies might relate to Scandinavia (because both involve islands). Thus Rimbert bound Adalhard, Wala and Corbie together with missionary prophecy and salvation. No doubt on one level such moves were justifying Anskar's past, but on another Rimbert was explaining how Benedictine rules could be overridden by abbots to help bring about a prophesised future, because they could send monks to be missionaries. This forward-looking aspect of Rimbert's text can be brought into focus if one considers the last eight chapters: rather than claiming that Anskar had converted the north, the story was left open-ended, with Anskar keen for others to take up his work.

The issue of stabilitas was important in Rimbert's presentation of Anskar as a pastor. The establishment of Christianity at a ping in Birka marked the culmination of Anskar's peregrinatio because he had fulfilled a vision that he had had in his youth about taking Christianity to the north. ${ }^{73}$ The concerns and well-being of his diocese, along with his vow of stabilitas, could no longer be ignored. The responsibilities of the mission in the north fell to Rimbert

68 The Rule of Benedict, ed. and trans. J. McCann, London i972, I, 6I, pp. I4-15, I38.

${ }^{69}$ Cuthbert Butler, Benedictine monachism, London I924, 327.

70 Pope Gregory I, Registrum epistolae viii.r8, MGH Epp., ii. 20-I; Rule of Benedict 67, pp.

I52-4; Butler, Benedictine monachism, 328.

72 Ibid. 25, p. 55 .

71 Rimbert, Vita Anskarii 7, p. 27.

${ }^{73}$ Ibid. 3, pp. 2I-4. 
and other priests. It is at this stage in the Vita Anskarii, when Anskar ends his active missionary life, that pastoral care is mentioned as a non-chronological insertion into the text. This has the effect of linking together Anskar's life as a missionary and as a pastor. But rather than using Gregory the Great's Cura pastoralis when discussing Anskar's time in Hamburg-Bremen, Rimbert drew on the work of Sulpicius Severus to stress Anskar's similarities to St Martin of Tours. ${ }^{74}$ Like Martin, ${ }^{75}$ Anskar wore cilicium, preferred solitude to company, was loath to move without strong encouragement and took care never to neglect his flock in favour of his own whims. As a result Anskar spent much time caring for the sick at a hospital in Bremen, much as Martin cured the many ill people he encountered in his life. The effect was to confirm that, although his missionary wanderings appeared to go against the Benedictine ideal of stabilitas, he had been a model of sanctity. It was a model that allowed space for missionary activities and asceticism, suggesting to Rimbert's audience that Anskar's monastic lifestyle was never forgotten. ${ }^{76}$ Missionary work in Scandinavia remained close to Anskar's heart, however, and it was his inability to bring it to a satisfactory conclusion himself that led to him writing the letter to the bishops of East Frankia.

Rimbert was careful not to encourage potential Corbie missionaries to go into the mission field without giving them some indication of what to expect. His set-piece missionary story reveals much about his intentions. There had clearly been some misgivings about Christianity in Sweden which had culminated after a particularly unfavourable winter in the ejection of Christians from the vicus in $845 .{ }^{77}$ In 852 , while in Denmark, Anskar learned that the issue would be discussed at a series of different councils where it was up to the community as a whole, not just the king, to decide. ${ }^{78}$ These appear strikingly similar to the Scandinavian meetings or pings which are evident in later sagas and place names, such as Thingwall in the Wirrall, and so cannot be dismissed as fanciful storytelling. ${ }^{79}$ Instead, here one might see Rimbert detailing the kind of processes future missionaries would have to go through in order to achieve some kind of success in Sweden. In his version of the meetings, Rimbert uses a priest-like character to provide an account of the nature and appeal of paganism in Sweden and offer reasons why the locals might be slow to follow the Christian God. Speaking for the local gods, the priest says, 'You have long since had our goodwill, and with our assistance you have inhabited the land you hold for a long time with many riches in peace and prosperity'; he

74 Ibid. 35, pp. 66-70.

75 Vie de Saint Martin, ed. and trans. J. Fontaine, SC cxxxiii, Paris I967, 9, Io, r6, pp. 270, $272-4,286-8$.

76 Sulpicius Severus, Vie de Saint Martin 6, I5, pp. 264, 284-6.

77 Rimbert, Vita Anskarii I7, p. 38; Annales bertiniani s.a. 845, 32.

${ }^{78}$ Rimbert, Vita Anskarii 26-7, pp. 55-9.

79 Else Roesdahl, The Vikings, trans. S. M. Margeson and K. Williams, London r998, 69. 
then continues by encouraging votive offerings to pagan deities and the adoption of a former king, Eric, as a new god instead of the Christian God. ${ }^{80}$ In the genre of hagiography it is exceptionally unusual to allow paganism a voice like this - one only has to compare the account of a pagan Saxon meeting in the ninth-century Vita Lebuini in which, rather than defending paganism, people threatened to throw stones at the missionary Lebuin. ${ }^{81}$ The inclusion of the speech in the Vita Anskarii must have been central to Rimbert's overall purpose in writing. Many today have doubted the historical accuracy of the priest's proclamations, but the concerns with offerings, the land, ancestors, riches and peace (or at least not losing battles) all portray common pagan ideals. ${ }^{82}$ Given Rimbert's interests in missionary activity and his time in Birka, it is highly likely that the speech was intended to inform future missionaries about the kind of challenges and attitudes that they would have to overcome there.

The speech also locates Rimbert's thoughts on mission amongst other approaches. It illustrates that Anskar and Rimbert were not quick to condemn the practices of the pagans but were instead committed to understanding pagan religion and refuting it intellectually, rather than by force. Bishop Daniel of Winchester had advocated peaceful conversion in a letter to Boniface early in the eighth century. ${ }^{83}$ Alcuin expressed similar sentiments in the Vita Willibrordi, which also expounded an idealised missionary blueprint, by telling stories of how Willibrord demonstrated the impotence of pagan beliefs. ${ }^{84}$ He even wrote a letter to Charlemagne on the matter. ${ }^{85}$ The advice was, however, ignored by Boniface, who allegedly destroyed a pagan shrine in Geismar, and subsequently by Charlemagne, who brutally forced the Saxons to convert and chopped down their Irminsul tree. ${ }^{86}$ The dangers of such an approach were highlighted later in the Vita Willehadi, according to which the destruction of shrines led to a pagan uprising in Saxony. ${ }^{87}$ Peaceably introducing pagans to Christianity was, of course, more in keeping with the Rule of Benedict followed at Corbie. ${ }^{88}$ There were drawbacks to such a gradual approach: maintaining Christian institutions was expensive, ${ }^{89}$ and

${ }^{80}$ Rimbert, Vita Anskarii 26, p. 56.

81 Vita Lebuini, ed. G. H. Pertz, MGH SS ii. 362-3. Compare also the speech of the Northumbrian pagan priest Coifi in Bede's ecclesiastical history of the English people ii.I3, ed. B.

Colgrave and R. A. B. Mynors, Oxford I969, 182.

${ }^{82}$ On Scandinavian religion see Peter H. Sawyer, Kings and Vikings: Scandinavia and Europe, AD 700-IIoo, London 1982, 31-43; Roesdahl, The Vikings, I47-6I.

${ }^{83}$ Die Briefe des Heiligen Bonifatius und Lullus, no. 23, 38-41.

${ }^{84}$ Alcuin, Vita Willibrordi Io, ed. W. Levison, MGH SS rer. Mer., vii. I24-5.

${ }^{85}$ Alcuini epistolae, no. Iı, ed. E. Dümmler, MGH Epp., iv. I58.

86 Willibald, Vita Bonifatii 6, ed. W. Levison, MGH SS rer. Germ., lvii. 3I; Annales regni francorum s.a. $773,34^{-5}$.

${ }^{88}$ Rule of Benedict 4, pp. $26-8$.

89 Richard E. Sullivan, 'The papacy and missionary activity in the early Middle Ages', Mediaeval Studies xvii (1955), 46-Io6 at p. 8I. 
the extra time Anskar and Rimbert took would have dragged the process of conversion out much further than Hamburg-Bremen could afford in the ninth century.

Rimbert can also be seen informing his audience about what to expect in the mission field when detailing Anskar's other strategies. The most important of these was to impress kings, local magnates and the general populace through the giving of gifts; the loss of such gifts to pirates in 829, for example, was lamented as a distinct blow to the missionary enterprise. ${ }^{90}$ These gifts may have to have been rather lavish to make any impression, since Rimbert alleged that every merchant in Birka already had Ioo lbs of silver to his name. ${ }^{91}$ The claim is certainly an exaggeration, although archaeological finds do show large flows of silver coins arriving in Scandinavia from the Islamic east. ${ }^{92}$ Anskar is also portrayed as being careful to obtain royal permission before preaching throughout the Vita Anskarii. Kings were thus at the centre of Rimbert's missionary ideas. How effective this might have been in practice is unclear. Frankish kings appear to have paid Danish kings little attention after the 830 and the suggestion is that a succession of civil wars had undermined royal authority in Denmark. ${ }^{93}$ The minting of coins, a traditional indicator of royal authority, appears to have ceased at this time. ${ }^{94}$ For Swedish kings, we have no evidence beyond the Vita Anskarii. A story about an exiled Swedish king, Anoundas, suggests that things were often no smoother. ${ }^{95}$ It is significant, therefore, that in the Vita Anskarii, courting the king's favour alone could only do so much; one of the most lamented set-backs of the mission was a civil war in 854 which wiped out the majority of Anskar's contacts at the royal court. ${ }^{96}$ Rimbert's strategy was tempered by an appreciation of the realities of mission. In this one can see a departure from the idealised blueprint of Alcuin's Vita Willibrordi, which displayed little understanding of the mission field itself.

The central place of kings in the Vita Anskarii, even if it is downplayed, raises questions over whether Rimbert was familiar with Bede's Historia ecclesiastica - another text that had promoted the virtues of mission. Wilhelm

90 Rimbert, Vita Anskarii Io, 24, 26, pp. 31-2, 52, 57.

91 Ibid. I9, p. 42. On the importance of this as a missionary strategy see Stevenson, 'Christianising the northern barbarians', I7 I.

${ }^{92}$ Bengt E. Hovén, 'On oriental coins in Scandinavia', in M. A. S. Blackburn and D. M. Metcalf (eds), Viking Age coinage in the northern lands: the sixth Oxford symposium on coinage and monetary history (British Archaeological Reports International Series 122, I981), II9-29; Thomas S. Noonan, 'The first major silver crisis in Russia and the Baltic, c. 875-c. 900', Hikuin xi (1985), $4 \mathrm{I}-5 \mathrm{O}$.

${ }_{93}$ K. L. Maund, "“A turmoil of warring princes": political leadership in ninth-century Denmark', Haskins Society Journal vi (1994), 29-48; Niels Lund, 'Scandinavia', in McKitterick, New Cambridge medieval history, ii. 202-27 at pp. 210-I2; Stevenson, 'Christianising the northern barbarians', I7 $1-5$.

${ }_{95}$ Rimbert, Vita Anskarii I9, pp. $4{ }^{\mathrm{I}}-3$.

${ }^{96}$ Ibid. 3I, p. 63. 
Levison was unsure whether there was evidence of verbal borrowings from the work, but was certain that it was influenced by Anglo-Saxon missionary history. ${ }^{97}$ It is unclear to what extent the monks at Corbie would have appreciated references to Bede anyway, since the nature of their library meant that they did not have a copy. ${ }^{98}$ More recently, Ian Wood has argued that Rimbert did not know the text because he had to write to Ratramnus to enquire about what degrees of relatives could marry, a question answered in the Libellus responsionum of Gregory the Great incorporated into the Historia ecclesiastica. ${ }^{\mathbf{9}}$ This may only imply that Rimbert did not have a copy of Bede to hand in Bremen, not that he had not read the book. Alternatively, he might have been confused by the stricter De consanguinitate which often circulated along with the Historia. ${ }^{100}$ No copy of Rimbert's letter survives and Ratramnus' letter is only known from a fragment; it is therefore difficult to know exactly what Rimbert initially wrote. Perhaps more certain is that Gregory's ideas would have spread with direct papal influence on the missions. In the model of Anglo-Saxons a century earlier, Anskar visited the papacy to receive sanction for his mission at the tomb of St Peter. Pope Nicholas I, meanwhile, was an enthusiastic admirer of Gregory the Great, referring to the conversion of the English several times in a letter to Khan Boris of the Bulgars and writing to King Horik II of the Danes as Gregory had written to kings in the sixth century. ${ }^{101} \mathrm{He}$ also seems to have thought of the two missions as part of a programme of extending papal authority. ${ }^{102}$ It is worth noting, in the context of the collapse of the missions, that Nicholas's immediate successors did not share his enthusiasm for mission, and contact with Horik II is not mentioned in the Liber pontificalis. ${ }^{103}$

The Vita Anskarii was deeply concerned with mission, because of apocalyptic prophecies, and how best to conduct mission. If we think back to Rimbert's assertion that he was providing a model to imitate, it is significant that Anskar was the ideal he was presenting to his audience. In the process he had to explain to the monks at Corbie why it was right, and even important, for some of them to become missionaries. There was, however, Ebbo of Rheims,

97 Levison, 'Zur Würdigung', 623 and n. I.

98 Ganz, Corbie, 67.

99 Epistolae varoriorum, no. I3, I57; Bede's ecclesiastical history i.27, p. 84; Wood, 'Christians and pagans', $5^{2}$.

100 Bede's ecclesiastical history, pp. lxii-iii. On the transmission of the Libellus responsionum see H. Chadwick, 'Gregory the Great and the mission to the Anglo-Saxons', in Gregorio Magno e il suo tempo, Rome I99I, i. I99-212.

101 Pope Nicholas I, Epistolae, no. 99, cc. iv, lxviiii. ed. E. Perels, MGH Epp., vi. 572, 590; no. $26,292-3$.

102 Ibid. no. 27, 293-4. See also, in a different context, the disgruntled comments of Gunther, a deposed archbishop of Cologne, who described Nicholas as '[totius] mundi se imperatore facit', in Annales bertiniani s.a. 864, 64 .

${ }^{103}$ On the lack of papal support after Nicholas I see Seegrün, 'Erzbischof Rimbert', 64. 
another model that Rimbert offered alongside Anskar to complement the missionary. It is that model to which I now turn.

\section{Rheims, Soissons and mission}

In Anskar's letter to the East Franks, it was clear that the missions were closely linked to Ebbo, archbishop of Rheims. The see of Rheims had great importance for the Franks because their first Catholic king, Clovis (d. 5 ${ }^{\mathrm{II}}$ ), had been baptised by Bishop Remigius. The office of bishop of Rheims was therefore highly prestigious. But Rimbert's decision to use Ebbo of Rheims as a prominent model in his work can initially seem peculiar: despite being a close friend of Louis the Pious, to whom he owed his elevation to the see, Ebbo's career ended in scandal following a series of revolts against the emperor in $83^{-}-4$, fuelled by the ambitions of the co-emperor Lothar. ${ }^{104}$ In 833, following a revolt by Louis's son, Pepin of Aquitaine, Lothar called a 'long-planned assembly' at which Louis was deposed in the face of a number of 'false charges' read out by, amongst others, Ebbo of Rheims. ${ }^{105}$ Ebbo was to regret his involvement against his friend: in 834 Louis was reinstated as emperor, and the following year Ebbo was deposed as archbishop for his alleged crimes. ${ }^{106}$ Despite a brief reprieve for Ebbo in 840 following the intervention of Pope Leo IV, the connection between Rheims and Anskar's mission was permanently severed in 845 when Charles the Bald had his own man, Hincmar, elected archbishop. ${ }^{107}$ Disapproval of Ebbo began to emerge, especially in the writings of Thegan of Trier. ${ }^{108}$ Even as late as I075 Adam of Bremen commented that Ebbo had a fama ambigua. ${ }^{109}$ Many writers of the ninth century also believed that the ills of the Carolingian empire stemmed from troubles of the 830 s. ${ }^{110}$ But in many ways the monks of Corbie could sympathise because their own abbot, Wala, had been a prominent, if unwilling, supporter of Lothar. This chapter of the life of Ebbo - and indeed Wala was studiously ignored by Rimbert in contrast to nearly every other history that mentions him; a silence which speaks volumes about how closely linked the missions were with Ebbo from the beginning.

104 For a fuller account of Ebbo's life see P. R. McKeon, 'Archbishop Ebbo of Rheims (8ı-33): a study in the Carolingian empire and Church', Church History xliii (I974), 437-47.

${ }^{105}$ Annales bertiniani s.a. 832, 833, 5-7. $\quad{ }^{\mathbf{1 0 6}}$ Ibid. s.a. 834, 835, 8-9, Io-I I.

107 Concilium ingelheimense, ed. A. Werminghoff, MGH Concilia, ii. 2, 79I-8I4; Hincmar, Epistolae, no. I86, ed. E. Perels, MGH Epp., viii. I. 190-4.

108 Thegan, Gesta Hludowici imperatoris 43, p. 232.

109 Adam of Bremen, Gesta hammaburgensis ecclesiae pontificum i.24, 28.

110 David Ganz, 'The Epitaphium Arsenii and opposition to Louis the Pious', in P. Godman and R. Collins (eds), Charlemagne's heir: new perspectives on the reign of Louis the Pious, Oxford I990, $537^{-50}$ at p. 54I. 
The prospects for mission in Scandinavia in the ninth century did not initially look good. In 804 or 805 Charlemagne had refused Bishop Liudger of Münster permission to preach in Denmark, presumably for fear that it would add to the growing anti-Frankish feeling in the region. ${ }^{111}$ However, the expansion of the Frankish territories soon slowed considerably: nobles were becoming increasingly concerned with their existing lands and less keen for expansion, so new ways of securing hostile frontiers were needed. ${ }^{112}$ Conversion seemed to offer Louis the Pious a way ahead that avoided the troublesome need for employing armies over prolonged periods of time. Thus in 82I - coincidentally the same year that Harald Klak joined the ranks of kings in Denmark ${ }^{113}$ - both Louis the Pious and Ebbo sought papal backing for a mission to the Danes in order to end the problems that had characterised the previous twenty years and secure the Danish frontier. ${ }^{114}$ Ebbo and Bishop Willerich of Bremen set out in 823 and worked as missionaries in Denmark for one year. Rimbert's account of the $82 \mathrm{I}-3$ missions was, however, made as another non-chronological aside. ${ }^{115}$ This deceit had the effect of giving Anskar's missionary activity in 826 primacy and casting Ebbo as more of a supporting figure. One might also wonder if the involvement of Willerich, Willehad's successor, had something to do with this downplaying of the early missions.

The first big success of the early missions came three years after they had concluded. In 826 King Harald and his followers, with increasing opposition at home and remembering Ebbo, approached Louis to seek baptism at Mainz. Ermoldus Nigellus, in a contemporary poem celebrating the event, was in no doubt that Ebbo's role as a missionary had been crucial. ${ }^{116}$ Ermoldus was equally clear that this was a most joyous time: Louis was seen to be at the height of his powers, and Harald's conversion to Christianity was a triumph of the highest order. However, Ebbo's success story soured following the Dane's enforced exile in 827 , subsequent treachery and turn to piracy. ${ }^{117}$ The result was that Harald's career created doubt over whether the missions were feasible. Notker of St Gall's 88os biography of Charlemagne, for example, included a story about northmen visiting the court of Louis the Pious to receive baptism over and over again in order to obtain gifts. ${ }^{118}$ It is likely that such a story, being set in Louis's time, was inspired by the memory

111 Altfrid, Vita Liudgeri i.Io, ed. G. H. Pertz, MGH SS ii. 407. For trouble brewing in Denmark see Annales regni francorum s.a. 804, i 18.

112 Timothy Reuter, 'The end of military expansion', in Godman and Collins, Charlemagne's heir, $39 \mathrm{I}-405$ at pp. $39^{2-4}$.

${ }^{113}$ Annales regni francorum s.a. $82 \mathrm{I}, \mathrm{I} 56-7$.

114 Pope Paschal I, Epistolae, no. II, ed. K. Haupe, MGH Epp., v. 68-70; Haas, 'Foris apostolus', 4 .

115 Rimbert, Vita Anskarii I3, pp. 34-5.

${ }^{116}$ Ermoldus Nigellus, In honorem Hludowici, bk iv, lines I-I I2, pp. 59-6 I.

117 Annales fuldenses s.a. 852, 4I-2.

118 Notker, Gesta Karoli magni imperatoris ii. I9, ed. H. F. Haefele, MGH SS rer. Germ., n.s. xii. $89-90$. 
of Harald's baptism, and clearly shows that the lesson of Harald's treachery still seemed significant decades later in relation to more recent examples. ${ }^{119}$

When Rimbert came to write about Harald's baptism, Ermoldus' joyous tone had been forgotten. ${ }^{120}$ Rimbert, no doubt influenced by plenty of hindsight, wrote of Harald as an uncouth barbarian with an ambivalent attitude towards Christianity. Furthermore, drawing a contrast to Harald, he emphasised the importance of the legitimate kings of Denmark and Sweden as conduits through which to convey the Christian message: the Danish kings Horik I and Horik II, and Swedish kings Bern and Olef, are all portrayed as being receptive towards the mission and open to the building of churches in the north, although there is no indication that any of them converted to the new religion. ${ }^{121}$ They are also distanced from any activities that may have reflected badly upon them: pyrates rather than Horik personally are made responsible for the destruction of Hamburg in 845 ; Horik II is represented as being misled by Hovi, the count of Hedeby, over persecuting Christians; and Olef explains that the 845 expulsion of Christians from Birka was undertaken without his consent. ${ }^{122}$ Through this deceit Rimbert could be seen to be countering the antipathy towards Scandinavian kings caused by Harald's later career and offering encouragement for future missionaries by indicating that they would be well-received in Scandinavia. It also reaffirms the traditional Gregorian model for conversion that centred on kings. But perhaps more significantly Ebbo, Ermoldus' hero, was expunged from the story of Harald altogether, separating him from the failures of the past. Again, this omission also helped cast to Anskar as the main missionary in the story, allowing Ebbo to be brought into the story five years after Anskar's first mission in the role of a model supporting figure, worthy of being emulated.

Ebbo's deposition from Rheims, however, disrupted the material support available to Anskar. Ebbo had taken care to make sure that the church in Birka was sufficiently funded and even sent his own nephew, Gauzbert, to be its first priest. ${ }^{123} \mathrm{He}$ had also distributed money from the monastery at Welanao (now Münsterdof on the river Sturia) which he later gave to Anskar. ${ }^{124}$ When Hincmar was appointed to Rheims, the new archbishop was at pains to disassociate himself from Rheims's recent past; there remained doubts as to the legitimacy of Ebbo's deposition and Pope Leo refused to acknowledge Hincmar's appointment while Ebbo was alive. ${ }^{125}$ Part of Hincmar's defence

119 For example Godefrid in Annales fuldenses s.a. 885, 102.

120 Rimbert, Vita Anskarii 7, p. 29; Wood, 'Christians and pagans', 36.

121 Adam of Bremen, Gesta hammaburgensis ecclesiae pontificum i.25, 31, was almost certainly misreading Rimbert, Vita Anskarii 24, p. 52, when he wrote that Horik was converted by Anskar. ${ }^{122}$ Compare Rimbert, Vita Anskarii I6, p. 37, and Annales bertiniani s.a. 845, 32.

${ }^{123}$ Rimbert, Vita Anskarii I4, p. $36 . \quad{ }^{124}$ Ibid. I3-I4, pp. 35-6.

125 Pope Leo Iv, Epistolae, nos 36, 37, ed. A. de Hirsch-Gereuth, MGH Epp., v. 6o4-5, 6o5-6; Celia M. Chazelle, 'Archbishops Ebo and Hincmar and the Utrecht psalter', Speculum lxxii (I997), I055-77 at p. I069. 
was to emphasise the illegitimacy of Ebbo's second episcopate between 840 and 84I. In order to underline the point, he had all the priests whom Ebbo had ordained during that period removed from office. ${ }^{126}$ This move was later condemned by Nicholas I. ${ }^{127}$ Hincmar's efforts were also illustrated by a representation of the Fides catholica in the Utrecht psalter, symbolically showing a figure receiving the pallium for his strenuous defence of Catholic orthodoxy at the Council of Nicaea. ${ }^{128}$ With Hincmar taking such a firm stance against everything connected to Ebbo's episcopate, it is highly unlikely that he would have maintained the financing of the church at Birka. In contrast to Ebbo's actions towards the Danes, Hincmar made it clear in an interpolation into Prudentius's Annales bertiniani for 84I, and in his own for 876, that he disapproved of the 'northmen' and attempts to convert them. ${ }^{129}$ Flodoard of Rheims, who venerated Hincmar, later famously portrayed Ebbo as fleeing to Denmark with the help of northmen, thus illustrating how the fall of Ebbo had become entwined with suspicion about mission at Rheims. ${ }^{130}$ The appeals of Anskar and Rimbert to east and west respectively, strongly suggest that there was a cessation of funds, because otherwise such pleas would have been unnecessary. However, Hincmar fell from favour with Charles the Bald in $873{ }^{131}$ as we saw with conditions surrounding Turnhout, the time was right to try and change attitudes to the mission. It is therefore notable that, in contrast to Hincmar's attitude, Ebbo was presented as being involved in the Scandinavian mission for the rest of his life. ${ }^{132}$ There is little doubt in Rimbert's writings that Ebbo, through his continuous support, was a model Christian.

The image of a supportive bishop was not necessarily something Rimbert intended to promote for the monks of Corbie to emulate. Verbal borrowings from the Vita Sixti et Sinicii in the Vita Anskarii perhaps indicate an episcopal audience for the text. Sixtus and Sinicius were two third-century missionaries who were credited with founding the sees of Rheims and Soissons. Their vita told the story of how, following the martyrdom of Crispinus and Crispinianus near Soissons, Sixtus and Sinicius were sent by Pope Sixtus I to preach to the heathens of Gaul because there were no pastors left there to tend to the people. ${ }^{133}$ After the founding of bishoprics at Rheims and Soissons, Sixtus died and soon afterwards Sinicius died too after bringing the faith to many; the two were buried side-by-side, together in death as they had been in life.

\footnotetext{
126 Annales bertiniani s.a. $853,42$.

127 Ibid. s.a. 867, 87; Pope Nicholas I, Epistolae, nos 79, 80, pp. 414-22, 422-31.

${ }^{128}$ Chazelle, 'Archbishops Ebo and Hincmar', Io69-70.

129 Annales bertiniani s.a. 841, 876, 25, I3I.

130 Flodoard, Historia remensis ecclesiae ii.20, ed. J. Heller and G. Waitz, MGH SS xiii. 472.

131 Janet L. Nelson, Charles the Bald, Harlow i992, 24I.

132 Rimbert, Vita Anskarii 34, pp. 65-6.

133 Vita Sixti et Sinicii, ed. J. v. Stilting, Acta sanctorum, Sept. i. Ist I25-7.
} 
The Vita Sixti et Sinicii is likely to have arrived in Bremen in 835 when relics of the two saints were translated there: Rudolf of Fulda recorded them amongst the many different saints' relics that were translated to Germania at the time, alongside those of Crispinus and Crispinianus. ${ }^{134}$ The majority of translations were made under the aegis of Abbot Hrabanus Maurus of Fulda, but it seems that it was Ebbo, just before his deposition, who was responsible for the bringing of Sixus and Sinicius to Saxony. ${ }^{135}$ The relics were taken first to Hamburg and then, after Hamburg was destroyed in 845 , to nearby Ramelsloh. ${ }^{136}$

The story of Sixtus and Sinicius found great resonance with Rimbert, which encouraged him to include borrowings from their vita. ${ }^{137}$ Predominantly, these borrowings are from sections on the successful preaching of the two missionaries and their deaths. The parallels between Sixtus and Sinicius, and Anskar and himself were clear. They worked in pairs in a dangerous pagan land that had no priests, converting many and building churches so that new converts could have pastors. Eventually, having achieved much, Sixtus and Anskar died, and Sinicius and Rimbert were left to continue their work. Rather than a morbid reflection on the recent past, it would have comforted Rimbert to know that Rheims and Soissons had grown from missionary beginnings into two of the most important sees of the Frankish empire. The borrowings might also have been intended to suggest some kind of unity between Hamburg-Bremen, Rheims and Soissons, and to impress upon the West Franks that historically they shared the burden of mission. ${ }^{138}$ Rimbert's use of the text strongly implies, as with most verbal borrowings, that he expected his audience to recognise the parallels themselves. There is reason to suspect that Rimbert's principal audience here was the bishop of Soissons, as the monks of Corbie had close ties with Soissons and even possessed a Passio Crispini et Crispiniani. ${ }^{139}$ Furthermore, Bishop Rothad of Soissons had continually supported Ebbo over Hincmar, even after Ebbo's death in 854 . Rothad was eventually deposed by Hincmar at a meeting at the church of Crispinus and Crispinianus in 86I, but Nicholas I had intervened and reinstated him in 865 , much to Hincmar's chagrin. ${ }^{140}$ There was a definite context here in which Rimbert could hope for support against Hincmar, and he might have hoped that bishops of Soissons could emulate

134 Rudolf of Fulda, Miracula sanctorum in ecclesias fuldenses translatorum I4, ed. G. Waitz, MGH SS xv. I, 339.

135 See Adam of Bremen, Gesta hammaburgensis ecclesiae pontificum i.I8 (20), 25.

136 Ibid. i.23 (25), 29.

137 Levison, 'Zur Würdigung', 626-8, identifies the specific borrowings with some discussion.

${ }^{138}$ On the use of saints' cults, and especially doublets of saints like Sixtus and Sinicius, to emphasise unity, see Peter Brown, The cult of the saints: its rise and function in Latin Christianity, Chicago I982, 86-104, esp. p. 97. ${ }^{139}$ Ganz, Corbie, I29.

140 Annales bertiniani s.a. 861, 862, 865, 56, 59, 76. Hincmar had been annoyed by Rothad to the point of calling him a 'homo singularis amentiae': Annales bertiniani s.a. 86r, 59 . 
Ebbo by supporting the missions. Despite borrowing from the Vita Sixti et Sinicii, however, Rimbert carefully omitted to mention the saints by name even when referring to their relics. ${ }^{141}$ This might be because of sensitivity over the relics' translation from Rheims, and might indicate that he hoped that Hincmar himself would read his work.

Quite what Hincmar made of the translation, it is impossible to say. It seems certain that he did read the Vita Anskarii, and may even have borrowed from it in his Vita Remigii. ${ }^{142}$ As was noted earlier, Hincmar had connections with Corbie in the 86os and 87os through Odo of Beauvais, so it would not have been difficult for him to obtain the text. The importance of Sixtus as the first bishop of Rheims was also not lost on him. When Pope Leo IV finally recognised Hincmar's appointment, the archbishop wrote a letter emphasising the (imagined) importance of Sixtus' see in having brought together Carolingian rulers and the papacy. ${ }^{143}$ It is unlikely, therefore, that Hincmar would have been impressed on arriving at Rheims in 845 to find the relics of Rheims's founding fathers missing, especially as 'relics were always for him the irreplaceable link with spiritual patrons' ${ }^{144} \mathrm{He}$ is even less likely to have been impressed if Ebbo had actually been involved. Yet, as is wellrecognised, it was the cult of Remigius that Hincmar was most interested in developing because of the saint's links with the rise of the Franks and their conversion to Catholicism. ${ }^{145}$ However, we may still wonder why Hincmar made inappropriate use of Anskar's pseudo-martyrdom as a model for Remigius' death; he constructed the Vita Remigii too carefully for it not to have some significance. Unfortunately, there is no certain answer, although the parallel may have been made to suggest that Hamburg-Bremen was but a pale imitator of Rheims and its glorious history.

When Rimbert came to write the Vita Anskarii, the prospects for the Scandinavian missions were looking bleak. Although Anskar, his illustrious predecessor, had written a letter to the bishops of the East Franks seeking support, there was no subsequent interest in the missions apparent under Louis the German. The missions were important to Rimbert because of his missionary, and possibly even Danish, background. But, more significantly, Rimbert saw his work as fulfilling the prophecies of Isaiah and Matthew that the end of the world would be preceded by the preaching of Christianity at the ends of the earth. After the failure of Anskar's letter, the genre of the saint's Life offered Rimbert the ideal vehicle to promote the mission: with its liturgical

141 Rimbert, Vita Anskarii I6, p. 37.

${ }^{142}$ Levison, 'Zur Würdigung', 620-I; Wood, 'Christians and pagans', 63 and n. I26.

${ }^{143}$ Flodoard, Historia remensis ecclesiae iii. Io, 483.

144 J. M. Wallace-Hadrill, 'History in the mind of Archbishop Hincmar', in J. M. WallaceHadrill and R. H. C. Davies (eds), The writing of history in the Middle Ages: essays presented to R. W. Southern, Oxford I98I, 43-70 at p. 44 .

145 Ibid. 63-70. 
uses, examples to be imitated and its mixture of literary and historical styles, it engaged the audience's intellect in a completely different way. Rimbert could therefore use the Vita Anskarii to encourage the Benedictine monks to suspend their vows and work in the mission field, while informing them of what to expect there. Furthermore, Rimbert could encourage bishops to become generous patrons of the mission to ensure that the plans came to fruition. Yet despite addressing the problems that the mission was facing through his text and his choice of audience, Rimbert's message does not appear to have been heeded. Throughout the 880s Scandinavians became unpopular, if not vilified, as viking attacks escalated, Paris was besieged and the imperial palace at Aachen was ignominiously used as stables by warbands. ${ }^{146}$ Then in 888 - the same year that saw the Carolingian empire effectively dissolved - Rimbert died and the missions collapsed; as Anskar had feared, the efforts of Hamburg-Bremen were forgotten and it was over a century more before Christianity was again preached at the ends of the earth. 